\title{
The Evolution of Sweden's Urban Sustainability Marketing Tool: A Comparative Study of Two Major International Events
}

\author{
Santiago Mejía-Dugand \\ Linköping University Post Print
}

Tweet

N.B.: When citing this work, cite the original article.

This is an electronic version of an article published in:

Santiago Mejía-Dugand, The Evolution of Sweden's Urban Sustainability Marketing Tool: A Comparative Study of Two Major International Events, 2016, The Journal of urban technology.

The Journal of urban technology is available online at informaworld ${ }^{\mathrm{TM}}$ :

http://dx.doi.org/10.1080/10630732.2015.1102422

Copyright: Taylor \& Francis (Routledge): SSH Titles

http://www.routledge.com/

Postprint available at: Linköping University Electronic Press

http://urn.kb.se/resolve?urn=urn:nbn:se:liu:diva-127483 


\title{
The Evolution of Sweden's Urban Sustainability Marketing Tool: A Comparative Study of Two Major International Events
}

\author{
Santiago Mejía-Dugand* \\ Environmental Technology and Management \\ Department of Management and Engineering \\ Linköping University \\ E-mail: santiago.mejia.dugand@liu.se \\ *Corresponding address: \\ Santiago Mejía-Dugand \\ Environmental Technology and Management (IEI). \\ Linköping University, 58183 Linköping, Sweden. \\ Tel.: +46 13 285639; fax: +4613149403 \\ E-mail address: santiago.mejia.dugand@liu.se
}

\section{Acknowledgements}

The author would like to thank ÅForsk and the Swedish Governmental Agency for Innovation Systems (Vinnova) for their financial support, and Em. Professor Leo Baas, Johannes Matschewsky, and Wisdom Kanda for their valuable contributions. Also, a big thank you to the anonymous reviewers, Marie Andersson de Frutos and Thomas Andersson from the Swedish Embassy in Colombia, and Christer Öjdemark from Envac AB. 


\section{Abstract}

In this article, some of the obstacles for translating urban imaginaries and urban sustainability concepts based on technological interventions are analyzed. This analysis is built on experiences from the World Urban Forum 7 in Medellin, Colombia held in April 2014, and uses previous attempts to explore the production of imaginaries at play in the performance of SymbioCity, an urban development concept with a symbiosis tint created by the Swedish Trade Council. Through documenting the role of physical and non-physical messages from the Swedish delegation and its exbibition, along with numerous interviews with key actors at the conference and from the city's administration, an analysis of the current strategies used to promote the tool is provided. The claim that induced idealized urban futures sap energy and result in poor achievement of the goals is used to suggest that context and current conditions influence the ability to understand and adopt technological solutions. The conclusions are centered on the fact that SymbioCity, for the most part, is trying to sell products or services that are difficult to see and understand from the perspective of citiescustomers, since most of these consist of invisible (i.e. energy), or hidden loops (i.e. waste and water). It is argued that there are contextual and historical conditions that are crucial for the decision to implement them that are, at least implicitly, expressed by the targeted cities-customers, and that the SymbioCity concept, or at least the way it is communicated in these fora, has undergone a change, in the sense that it has become more flexible and allowed for bottom-up considerations to enter the discourse. 
KEYWORDS Sweden; Hammarby Sjöstad; Urban Technologies; Export Model. 


\section{Introduction}

Cities are the cornerstone of the Anthropocene. The unprecedented migration from rural to urban areas has resulted in both benefits and disadvantages for humans and the surrounding environment. This, in turn, has created a new market in which cities compete fiercely: "the sustainable city." Although for many broad and controversial, the term "sustainability" has become a very popular marketing tool (Wangel, 2013). It is widely used to sell "hard" products (e.g. cleaning technology, transportation technology and energy solutions), "soft" products (e.g. policy design and advisory services) and to attract international attention (e.g. foreign investment, professional talent and tourism) (Bulu, 2014; DiGaetano and Strom, 2003).

Since environmental technologies are trusted by many to provide strong foundations for both environmental sustainability and economic growth (Kanda et al., 2015), the urban era represents tremendous opportunities for the diffusion of these types of solutions. In this line of thought, countries and cities with an advantageous position in international markets (i.e. because of their reputation, industrialization level, political influence, and even cultural and geographical characteristics) are exploiting this condition, and creating strategies and devoting important resources to promote the solutions they claim as theirs or the know-how they have accumulated from their own experiences.

Nevertheless, the difficulties of translating imaginaries of sustainability are starting to become a concern for researchers and decision-makers, especially under such a globalized environment (see e.g. Hult, 2013). Hult (2013) critically analyzed the strategy that the Swedish government and the export-promotion agency Business Sweden (at that time called Exportradet) are using to promote urban technologies. She analyzed the marketing platform adopted for this purpose, SymbioCity, and the imaginaries at play when Sweden presents a transferrable image of a model that might underestimate important contextual characteristics.

Sweden, and some of its cities (e.g. Stockholm, Gothenburg and Malmö), can be said to be part of the "usual suspects" when it comes to urban sustainability (together with other Scandinavian, Western European and North American cities; see McFarlane, 2010). However, not only can modern cities more easily access information about the market and its players than before, but higher levels of governance and transparency have created hostile conditions for the adoption of magic-bullet solutions. Contextual characteristics translated into existing systems, and the impact of their relations and coexistence of the new ones with them, are steering the process of successful technology adoption and diffusion at the urban level (Mejía-Dugand, 2013; Mejía-Dugand et al., 2013b).

Hult (2013) critically assessed the static nature of the Swedish message regarding progress and space. Her study included experiences from her visit to the Swedish Pavilion at the World Urban Forum in Nanjing in 2008 and the World Expo in Shanghai in 2010. What has changed in the Swedish strategy to export its concept of sustainable urban development? This is an interesting question to ask because Sweden is considered in many milieus as a leader in the development of environmental technology and because of the sustainability standards of some of its cities (see e.g. 
WWF, 2014; Yale University, 2014). I visited the World Urban Forum in Medellín, Colombia, in 2014 with the aim to find an answer to this question.

\subsection{Critiques to the Model - Hammarby Sjöstad as the Most Common Proof-of-Concept Example}

The SymbioCity model is a tool developed by the Swedish Trade Council (i.e. Business Sweden) to help Swedish environmental technology providers to expand their business into foreign markets. In recent years, the identification of environmental technology as a potentially central component of Sweden's economic growth through international expansion (i.e. through exports) has become more explicit (see e.g. The Swedish Government, 2008; 2011). However, as Hult (2013) and Pandis Iveroth et al. (2013a) note, efforts to promote the concept of sustainability in general, and urban sustainability in particular, go back to the beginning of the century in this country.

In 2005, the Swedish Environmental Technology Council (Swentec) was created by the Swedish government with the goal to perform studies about the status of environmental technology providers in Sweden by making inventories of the available offerings and companies, and assessing strategies for the expansion of the sector into international markets. After years of work, the commission presented a report in 2010 that suggested different strategies in line with their findings. Among others, an important suggestion was the promotion of proof-of-concept projects, i.e. showcases for potential customers to see the actual operation of technological systems. Although many examples could be found around the country and had been running for many years, Hammarby Sjöstad, a relatively new residential project located in south-east Stockholm, proved to be an excellent example. This was to a great extent due to the fact that the area where it was built was an old industrial area with high levels of pollution and which was to some a "shantytown" (Pandis Iveroth et al., 2013b). A model called "The Hammarby Model" was actually developed and widely promoted (Pandis Iveroth, 2014). The area had already attracted a lot of attention from locals, since the city had suggested the construction of the Olympic Village when it applied to host the Summer Olympic Games of 2004 (Pandis Iveroth, 2013b; Wangel, 2013), and as Hult (2013) notes, it was considered as a "dream city district" by Chinese politicians.

Commercial tools such as Simbiocity are difficult to connect directly to successful business (Kanda et al., 2015) since they are normally not the only efforts a company sets into for the expansion of their businesses. In its official website it reads: "SymbioCity is an entry point to holistic and sustainable urban development" (SymbioCity.org, 14 May 2014). However, Symbiocity has been criticized before due to the difficulties it faces when translating sustainable urban development imaginaries into different contexts, relying on values and habits that are inherent to the Swedish culture, and the high investments and long time that implementing such a holistic model would require (Hult, 2013; Mejía-Dugand, 2013; Wangel, 2013).

Although it is not widely known abroad, Hammarby Sjöstad, one of the central flag projects and usually presented in international fora as the best example for the application of the SymbioCity concept, has received harsh criticism in Sweden. Wangel (2013), for example, states that many of the 
initial goals set when the development was planned were never met, especially regarding energy efficiency. This is also supported by Pandis Iveroth (2014), who adds that the evaluation and assessment of the goals were not worked out properly. Wangel (2013) also states that since the beginning, developers claimed that such goals would harm the comfort of the residents. Another point for criticism comes from the fact that the location, the environmental profile and the technical systems in Hammarby Sjöstad have made the project accessible to a specific group of individuals or families able to pay the prices in the area. Such a condition, as Wangel (2013) notes, might contribute to segregation in the city and leave a certain population outside the coverage of environmentallyfriendly technologies. Pandis Iveroth et al. (2013b) describe multiple closed loops and discuss the environmental benefits of such a condition, but Wangel (2013:98) says that flows of energy, materials and waste in the area are "far from being closed." In addition, and central to the criticism that Wangel (2013) and Hult (2013) give to SymbioCity, the idea of sustainability is sold abroad connected to the decoupling of Sweden's economic growth from $\mathrm{CO}_{2}$ emissions. However, as these authors highlight, this is only defendable from a production perspective, while from a consumption perspective it is not the case. In particular, the socio-economic characteristics of Hammarby Sjöstad have an influence on consumption of goods produced elsewhere.

Finally, Sweden faces a tremendous challenge for the export of its technology. As mentioned above, much of the concepts promoted by the SymbioCity tool are based on municipalities/cities/neighborhoods. This means not only that the adoption and operation of systems are embedded in values and cultural and political traditions (as was mentioned above), but also on the expertise of municipalities and their municipal companies. Kairento and Nygarrds (2014) and Eriksson and Nilsson (2013) discussed barriers, incentives and possible strategies for municipal companies to exploit their experience and know-how. They found enormous obstacles of a legal (e.g. by law, municipal companies are not allowed to risk taxpayers' money in foreign markets) and technical nature; municipal companies have the logistical, regulatory and operational know-how, but do not have production capacity, which hinders the export of their products/services. This is also the case for the Swedish environmental technology sector in general, since small and medium-sized companies, which represent a large share of the whole sector, have difficult times trying to fulfill orders from large cities-not to mention from the nowadays so-common megacities. These are common concerns also among Swedish municipalities and governmental agencies, as expressed in national conferences discussing these topics.

It is evident that many cities do not have the knowledge or the capacity to build technical systems to counteract the harmful effects of other technologies, uncontrolled sprawl and migration from the countryside. Imported knowledge and technologies are an undeniable contribution to these challenges, but must be analyzed cautiously due to the conditions under which they enter the recipient socio-technical systems. Sweden is an interesting case to analyze due to its position and reputation worldwide regarding environmental protection and technical innovation. It is of much relevance thus to understand how the country's strategy evolves and adapts to the requirements of potential adopters and the nature of their socio-technical regimes. 
In particular, I am interested in Sweden's marketing tool for the promotion of environmental technologies and urban sustainability concepts (i.e., SymbioCity), and its evolution in comparison to past events, such as the World Expo in 2010 (see Hult, 2013). With this in mind, the aim of this article is to describe and analyze urban imaginaries, as expressed by the Swedish delegation attending the 2014 World Urban Forum 7, in order to find patterns and characteristics that can be of help to critically assess its approach to sustainable urban development. Relevant questions to support this aim are:

- Has the message conveyed by the Swedish delegation changed in relation to previous events of this kind?

- Is the focus on holistic solutions compatible with the urban imaginaries of targeted citiescustomers?

- What are the main obstacles for the export promotion tool used by the Swedish government (i.e. SymbioCity) to convince and deliver to cities-customers?

By answering these questions, it is possible to assess if contextual characteristics are gaining importance and are shaping the strategies used to convey a message and deliver a technology. It is also possible to understand the power that recipient cities have gained in a recently-declared urban world, in which the competition for the "sustainable city" is fierce.

As mentioned before, such strategies have been previously studied and critically evaluated. In particular, the work done by Hult (2013) provides a solid point of departure as it laid the foundation for the assessment of Sweden's tool to approach urban sustainability and the translation of values and socio-technical systems into the potential recipients' language. In order to achieve this, empirical data were collected in April 2014 during UNHABITAT's World Urban Forum in Medellín, Colombia. Such data were collected mainly in two ways:

a) Observational studies: the roles of physical and non-physical messages from the exhibitors were documented by visiting the different exhibitions at the forum. Special attention was devoted to the Swedish delegation in order to analyze the current approach and the changes it might have suffered compared to past experiences (as documented by e.g. Hult (2013) and Mejía-Dugand (2013)).

b) Interviewing and direct interaction with those in charge of the exhibitions: semi-structured guides were designed in order to find relevant characteristics of each approach, guiding principles, and obvious and apparent strategies. Furthermore, interviews with the Swedish Embassy and the Swedish Trade Council in Colombia provided additional insights on the development of the delegation's strategies. Other actors from the local administration and the municipal utilities company (previously contacted during an earlier visit to the city of Medellín) found to be relevant were also included in the interviews.

Comparative Urban Studies, Diffusion of Innovations and Social Psychology theories provided the foundation for the analysis and conclusions in this article. The first two are relevant for the 
analysis of urban imaginaries because they provide foundations to understand the requirements that foreign formulae must consider when introduced into new environments. Social Psychology, and in particular the work of Oettingen and Mayer (2002) and Kappes and Oettingen (2011), provides useful tools to understand the impact that imposed imaginaries-rather than imaginaries built on previous experiences and contextual implications-have on the adopters' understanding of the benefits and applicability of a given technological solution, and on the actual achievement of future goals.

\section{Translating Imaginaries - The Problem of Scale and Culture}

During the World Urban Forum in Medellín, Sweden presented, for a whole day and in a private auditorium, its approach to sustainable and inclusive cities (more will be discussed in Section 4). One of the presenters was Christer Öjdemark (the $\mathrm{CEO}$ of Envac AB, a waste collection technology supplier), who presented the system, the benefits it brings to the implementers and, most importantly, where it has been implemented. Attendees were mainly concerned about the costs (e.g., one interviewee mentioned that a particular neighborhood in town could be covered with two collection trucks ten times less costly than with Envac's system), to which he replied that the additional cost of the system is normally covered by higher real estate value and lower operational costs. Another concern came from a local institution working with informal waste pickers and recyclers: What would become of them with the new system? Öjdemark highlighted that it is not a matter of two competing systems: recyclers only pick what is valuable, but someone has to pick what is left. It became evident that Envac's experience working abroad has given them the tools to address such issues, and has taught them the important role that contextual conditions play in the technology adoption process.

On the other hand, representatives from the city of Malmö had a more difficult task, i.e. to present a much wider picture of urban development, based on the experiences of their own city. The challenge for them was to get more than people's curiosity: It was how to show Sweden's sustainable cities concept. This was done by presenting different projects to recover urban areas and in particular public spaces, projects of social inclusion (Malmö has one of the highest percentages of immigrants in Sweden) and gender/age equality considerations. From the audience, it was possible to experience the "discomfort" with some of these projects. In particular, one man said: "We are talking then of a city of 300,000. Bello alone [a municipality north of Medellín] has 600,000 inhabitants." A woman reacted to a picture showing the improvement of a neighborhood with an empty street by saying: "Where are the people and the cars?" A similar question was directed at the presenter who was in charge of explaining the SymbioCity concept: "What is the largest city you have worked with?" This is to show the immense gap that opens when people do not see similarities between what they are shown and what they experience every day. This issue will be addressed later.

Other presenters included private companies like Volvo, Scania, Folkhem and WSP. Volvo and Scania presented their products, which are already widely known in the region, and of course mentioned the benefits they bring to the city and its environment. However, there was no easilymade connection to the SymbioCity concept. In other words, the size and presence of these 
companies in the region give them independence, and although sustainable transport is a part of the SymbioCity concept, one can say that it belongs to a higher level when it comes to thinking of sustainable cities, not easily shown with a picture of Hammarby Sjöstad. Folkhem presented their technologies for multiple-story wooden buildings. Their presentation was appreciated by the audience, who were concerned about costs (a large part relies on imports of wood and pre-fabricated elements) and about the use of local materials and labor, something addressed by the representative of WSP, who highlighted the need to involve important stakeholders as early as possible in transformation processes and to build on existing knowledge.

\subsection{Contextual and Current Conditions Influence the Ability to Understand Technological Solutions}

Kappes and Oettingen (2011) suggest that thinking about idealized futures is an energy-demanding process and that positive fantasies result in poor achievement, especially when they are induced. In contrast, fantasies that are less positive include the consideration of obstacles and hindrances for their achievement, which in turn motivate individuals to achieve their goals more successfully. This could be applied to the process of urban improvement or urban sustainable development, especially under current conditions and particularly in transitional ${ }^{1}$ societies. The new urban era, in which information is readily and easily accessible, and in which citizens and politicians can learn from good practices and mistakes made by other societies, has facilitated the emergence of more self-aware governments and societies (Mejía-Dugand et al., 2013b).

In many cases, and in particular in the case of Medellín, decentralization and autonomy have played a central role in the development of the city. Many cities in the developing world (as represented by their officials and citizens) have learned to trust their own knowledge and to be aware of the need to implement compatible and flexible systems that decrease the disturbance caused to the existing ones (Mejía-Dugand et al., 2013b). Governance levels have increased dramatically due to citizen education and widely-spread information and communication systems. In these cities, according to Mejía-Dugand et al. (2013b), solutions that are planned to a large degree by external actors make people suspicious and distrustful. Perhaps, as Kappes and Oettingen (2011) note, they have also realized that the sole process of putting together an idealized future based on alien values and habits has the risk of missing out on important conditions that could affect the intervention's success, not to mention the resources such a process would require. Oettingen and Mayer (2002:1198) also report that "[a]lternative forms of thinking positively about the future, which are based less on past experiences, [...] seem to be less beneficial for effortful action, performance, and well being" (emphasis added). How does a concept like SymbioCity fit into this assertion?

From a different perspective, Rogers (2002) describes five conditions for the successful implementation of (technical) innovations that are relevant considering what has been discussed so far: relative advantage (i.e. degree to which the new idea is perceived as better than the one it supersedes), compatibility (i.e. degree to which it aligns with existing values and past experiences), complexity (i.e. how difficult it is to implement and operate the new system), trialability (i.e. degree to which a system can be put to test on a chronologically-limited basis) and observability (i.e. the degree 
to which the results are visible to others). In this line of thought, complex (holistic) systems such as the ones proposed by SymbioCity face enormous obstacles and do not perform that well if analyzed under Rogers's conditions. One could argue that the system's relative advantage on other systems, especially existing ones, is evident in most of the cases, i.e. the mere intention of urban renewal implies that the existing systems are not optimal. However, the remaining conditions are difficult to defend, at least if the whole holistic model is to be evaluated. This is not the case for individual components, or at least not for all of them, something discussed by Mejía-Dugand et al. (2013a:10), who claim that the reference system (i.e. Hammarby Sjöstad) is presented as a "giant clockwork coordinated concept," which makes it difficult to comprehend it to a full scale.

How these conditions have influenced the way in which the Swedish delegation conveyed the message under the particular context of the World Urban Forum in Medellín is discussed in the following section.

\section{Waste Collection: The Most Visible Component in the "Hammarby Model"?}

The whole concept of a city (or district) where all material, energy and waste flows behave as closed loops is difficult to see, since most of them are physically invisible (e.g. heat and electricity) or are buried underground (e.g. water and wastewater). Solid waste, however, has different characteristics.

The provision of public services (e.g. utilities) relies on physical infrastructure configured as a network that connects production with consumption and can be owned completely by private companies. This is not normally the case for waste collection (i.e. as a public service), since it uses the actual road infrastructure (i.e. devoted to transport of goods and people), which is public property (Botero García and López Álvarez, 2005). However, this concept has changed in Hammarby Sjöstad, where solid waste collection is performed underground through a suction system that not only takes the collection trucks and the waste bins out of the streets, but also allows for the entrance of new actors (i.e. private) into the waste collection business. The city's government, in turn, can benefit from renting the underground (in many cases public property), and the avoidance of maintenance costs for the roads (e.g. deterioration and cleaning), traffic and logistics problems and even health issues related to disease vectors and bad smells.

One can say that the waste collection system is central in the SymbioCity concept, and one company in particular has benefitted from this, namely Envac AB. Envac is the only supplier of these underground waste collection systems in Sweden, and was one of the first companies to join the SymbioCity group. In many cases, the benefits of this system have shown to be easier to see and

understand from the perspective of potential buyers. When city officials visit Sweden to see many complicated and connected systems (Hammarby Sjöstad's holistic approach), they are usually impressed and many even "order one." However, as it was mentioned above, the operation of such systems is tightly connected to local values, regulations and physical conditions, and is thus difficult to cut and paste as a template elsewhere. Envac's system, on the other hand, has been shown to be useful and compatible, at least, to local regulations. In particular, as was the case with Hammarby Sjöstad, it has been shown to be useful for brownfield or urban remediation/renewal processes, so 
popular nowadays. Although the system is hidden underground, collection/separation points are visible, and most importantly, the results are explicit, i.e. no bins, garbage bags, collection trucks and bad smells. This is not necessarily the case with e.g. energy efficiency solutions, biogas and biofertilizer production.

These conditions have allowed for the system to be translated more easily into other contexts, since distrust is more easily overcome when potential implementers see the benefits explicitly and can see the new system's compatibility with their own vernacular systems (MejíaDugand et al., 2013b). Of particular interest, Barcelona implemented the system when it hosted the Summer Olympic Games in 1992. The system gained momentum when it was implemented outside Sweden. In particular, and of outmost importance to this study, Medellín has started the process of implementing this system. The city officials, with the help of the Swedish Embassy in Colombia and the Honorary Consul in Medellín (who has been a central figure in the development of this implementation and lived in Hammarby Sjöstad for two years), got acquainted with this solution. Although Hammarby Sjöstad was of course a reference project, it has been Barcelona where city officials have found it easier to understand the contextual implications of such a system. Envac's expansion to other continents has required the opening of regional offices. In this case, the satellite office in Madrid has been in charge of administering this project, not only for obvious reasons (i.e. language and cultural ties), but also because of the close political relationship the city of Medellín has with some Spanish cities.

For cities-customers that are both geographically and culturally distant (see Stöttinger and Schlegelmilch (1998) for a discussion on "psychic distance"), contextual implications play a central role in their technology adoption decisions (Mejía-Dugand, 2013). In the case of Medellín, for instance, an important ongoing project is the renewal of an old, impoverished area located in the center of the city (i.e. high-value land with close connection to the city's services, but with difficult social conditions). This area is, as of today, basically composed of heavy and lightweight vehicle repair workshops and a network of small businesses revolving around informal waste picking and recycling activities. This renewal project has very similar conditions as projects developed in Barcelona in the 80s, i.e. El Rabal and 22@, where Envac's system is implemented, not to mention certain similarities with Hammarby Sjöstad before its intervention.

The system is planned to be implemented in new residential and commercial buildings that would pay for the cost privately, i.e. included in the cost of the property. There are some obstacles for the installation of the underground networks (mainly due to the lack of planning/technology when the systems were laid many years ago and the preoccupation from the local utilities company that pipes and lines that are still usable might suffer). However, private actors will be in charge of laying the pipes once these obstacles are resolved. The developers, together with the municipal agency in charge of this project, promote the benefits of the system, and what is more important, are designing and suggesting strategies for the maintenance of the system through sorting and recycling activities, already present in the sector. 
The system faces of course serious challenges regarding its compatibility with existing systems: the old and unmonitored underground pipe system and the difficult social context (i.e. informality and crime). These challenges have to be solved by the city administration and the developer. There are already initiatives in place to address the latter, as stated by one interviewee. Regarding the old pipe system, negotiations and technical studies are already taking place. The need to invest in concomitant infrastructure is latent, and it is necessary to reach relevant agreements with the owners of the existing pipes (e.g. the local utilities company) and with the city administration (the underground is public property).

The case of underground waste collection is relevant to illustrate the barriers that urban technologies must overcome in order to be properly translated into a language that recipients can understand, and offer the highest possible degree of compatibility with existing values and conditions at the socio-technical level. This will be further analyzed in the following section.

\section{Swedish Exhibition at the World Urban Forum 7 - What has Changed?}

As was mentioned before, Hult's (2013) analysis of Swedish imaginaries at the World Expo in Shanghai 2010 is an important starting point for this article. It is thus important to start by mentioning that it is clear that these two events (i.e. The World Expo and The World Urban Forum) are different in scale and aims. Still, the World Urban Forum 2014 had around 22,000 visitors, which makes it the largest so far, not to mention the relevance of such an event for the promotion of urban concepts and technological solutions.

As Hult (2013) describes, the SymbioCity concept plays a central role in the way Sweden presents itself abroad. That being said, it is relevant to add that SymbioCity was not the central concept in Sweden's pavilion at the World Urban Forum 7. This means that there was evidently a different focus in comparison to what Hult (2013) reported, in the nature of the pavilion, the physical and non-physical messages and the focus. For a start, the pavilion was open and did not have guided tours, but rather different representatives talking about the different projects or technologies, or answering general questions. Second, there were no characters depicting Swedish culture or addressing particular groups of people. Third, there was no explicit focus on Swedish lifestyle, but a more nostalgic imprint of how life is when surrounded by natural materials, i.e. wood. The pavilion was built in wood shipped over the Atlantic from Sweden, although one section had a metal container (probably intended to highlight the ease with which wooden, pre-fabricated parts could be shipped). The decorations were simple and included some posters (talking about e.g. the city of Malmö, Sweden's timber industry and even international collaboration projects from Academia), innovative wooden furniture (i.e. chairs) and wooden pieces with which attendees could interact and build models.

The fact that SymbioCity was not explicitly present in the physical exhibition of the delegation does not mean that it did not play an important role in Sweden's participation at the Forum. However, this happened in a different manner. The Swedish Embassy in Colombia (which is the second largest in the Americas) has close relations with the city of Medellín, as it has been 
involved in urban renewal projects, and in innovation promotion and social programs. This probably facilitated the delegation's arrangement of a parallel event, held at the facilities of the city's utilities company, where only Sweden would present for a whole day. This means that the seminar arranged by the delegation had to compete with numerous and diverse events from the central organization of the World Urban Forum. Invitations were sent to different people, although there were also printed invitations at the pavilion. Still, it seemed that attendees to this event would have to have a specific interest in the country and its offerings.

As mentioned above, the seminar was a mix of actors from numerous backgrounds: city representatives, private companies, academia and governmental agencies. What was more interesting this time was the approach of the presenter in charge of discussing the SymbioCity approach. Hult (2013) expressed her concern about democracy, equality and justice issues being overshadowed by environmental technological solutions. Mejía-Dugand (2013) raised similar concerns regarding the contextual characteristics and the systems with which new technological solutions would operate, something that Mejía-Dugand et al. (2013b) analyzed in more detail with transportation projects implemented in Latin America. Wangel (2013) wondered who it is that will benefit from the sustainable city concept and criticized the efforts of exporting environmental technology and sustainable cities as a sort of "lifestyle imperialism." This concern had been raised before by Stevens (1991, quoted by Huesemann and Huesemann (2011)), who stated that the values and ideas of the society developing certain technology are embedded in it and are inevitably exported along with it. Hult (2013) holds that the linear view of development as technological interventions sticks to a particular path while ignoring or repressing other trajectories.

It is important to note that Hult (2013:91) mentioned in the epilogue of her article that "SIDA [the Swedish International Development Cooperation Agency] and SKL [a company owned by the Swedish Association of Local Authorities and Regions focused on the development of local government systems in developing countries and countries in transition] are developing the SymbioCity approach to a methodological handbook." This seems to send a signal that the criticism exposed above might have permeated those involved with the promotion of SymbioCity. It is clear that the ultimate goal of this tool, i.e. the promotion of the export of eco-profiled technology, has not changed-but the message has.

SIDA and SKL work mainly with international cooperation projects. They have been seen by some as "door openers" for environmental technology suppliers in developing countries (see e.g. Mejía-Dugand, 2013), taking advantage of locals that have been trained by them and can facilitate market entrances, legitimacy and access to distribution networks (ITPS, 2008; Swentec, 2010). This was the approach that the Swedish delegation took during their seminar in Medellín. SKL's representative discussed the importance of decentralization (a central topic for debate during the Forum), local democracy and local governance. Decentralization and autonomy as a part of Swedish political life since 1862 were highlighted, as was the fact that the host city, i.e. Medellín, had similar conditions. According to the presenter, this is unique on a global context. Although it was emphasized that they have not performed many projects in Latin America, there are many possibilities to exchange experiences and expertise. This is important in an urban context, in which 
previous "developmentalist" and neo-colonialist models limited city-to-city learning and useful interactions (McFarlane, 2010).

After this discourse, mainly centered on cooperation and collaboration, the presenter proceeded to talk about the SymbioCity concept. But the message changed: from a technology and culture-based one, as described by Hult (2013), to one focusing on local circumstances, partnerships between cities and capacity building. Wangel (2013) would probably stick to her criticism of "lifestyles imperialism," as the framework presented by SKL teaches those involved "how to think and how to implement" and then provides a platform to promote a network comprised of the private sector, academia and municipalities from Sweden (the commercial side of the tool). With this message, it was also conveyed that this approach is centered on symbiotic relations, but from the people's perspective (cf. Hult (2013) and Wangel (2013) who say it is evidently based on technological interventions). We can see therefore that at present, the discourse constantly shifts from cooperation to commercial and from people-centered to technology-centered: after SymbioCity came Envac, Volvo, Scania, WSP and Xylem, other Swedish technology suppliers.

The importance of the interaction of the different actors involved in the transmission of urban imaginaries is receiving more attention from those in charge of developing export strategies. This is evident in the way that the SymbioCity tool was presented at this event. The particular nature of the methods and technology discussed in these kinds of fora requires a deeper commitment of all the actors with the ultimate goal, i.e. sustainable urban development. This is due to their scale and ability to impact the lives of millions of citizens, and the need to fight the inherent blame that technology, as a general term, brings along for being one of the main causes of environmental distress in the first place. Suppliers of environmental technology, in particular, must overcome the fear of adopting new technologies. Even if their offerings are considered state of the art, adopters face what Huesemann and Huesemann (2011) call "the myth of value-neutrality," i.e., that technology is a neutral tool and negative consequences of using it actually depend on who controls it (and how). This condition raises important concerns about what kind of knowledge will remain with the adopting city and how the city will be able to adapt and influence the use of any given technology in a convenient and sustainable way. This is particularly true when the decision of adopting a certain technology is open for scrutiny and requires large amounts of resources (e.g. in terms of money and space), which is the case of cities.

\section{Conclusions}

As mentioned above, directly assessing the impact that a particular tool such as SymbioCity has had on the actual business activities and exports of environmental technology companies is difficult, if not impossible. This is due to the fact that companies do not only rely on such a tool for their operations; it is but one of the strategies contributing to them. However, it is important to understand what it is that marketing tools such as SymbioCity are really selling.

This question is not so easy to answer, and it is argued that it is even more difficult to define who has the responsibility of selling. This means that the idea of selling a whole district is far from 
realistic, especially in the developing world. Only a few countries, e.g. China and the United Arab Emirates, develop whole cities from scratch. Most have to deal with what they have and change it little by little. What does a city sell and who is the customer? Most of the time it is politicians that visit e.g. Hammarby Sjöstad. Many of them leave impressed and with the intention to "buy one" for their cities. But what is there to buy? Technological solutions that are not always visible (i.e. energy and material loops) and whose applications and results are difficult to translate into many of the languages that transitional cities and other cities-customers speak represent an enormous challenge for any marketing tool.

As was discussed in Section 3, particular components of the SymbioCity concept have benefitted from this marketing tool. However, this is not necessarily because of the whole symbiotic idea, but because of the role their technologies play and the actual visibility they have in the whole concept. Also, as was mentioned before, the actual ability to provide proof-of-concept examples in similar conditions, and the experiences accumulated by actually working outside Hammarby Sjöstad under conditions to which cities-customers can relate, play a central role in these companies' success. Other companies, such as Volvo, Scania and WSP, are not really part of the everyday symbiotic relations happening inside the district, due to their scope and reach. They are, of course, an important component of the whole "sustainable city" concept, but it is difficult to find a direct relation between them and one neighborhood that, as Wangel (2013) mentioned, has very particular social characteristics.

This article had Hult's (2013) study as a departure point. The aim was to critically assess the message conveyed by the Swedish delegation to the World Urban Forum held in Medellín in April 2014, and see whether it had changed in comparison to previous events. From the discussion presented above, one could conclude that it has, or at least that it has become more flexible and dynamic. For a start, it was described that the SymbioCity concept was presented not by fictional characters such as Erik Fun, Victoria and Pippi Longstocking (Hult, 2013), but by a representative from the Swedish international cooperation agency and the Swedish municipalities association. This time the message was conveyed with a local and people-centered tone, which expresses a migration from a top-down to a bottom-up, more collaborative than imposing approach (or what Wangel (2013) critically calls "lifestyles imperialism").

The findings presented in this article regarding the evolution of the SymbioCity tool and the Swedish delegation's approach to translating urban imaginaries are relevant in a globalized context in which cities compete for international attraction, many times relying on technological interventions. The term "urban sustainability" is strictly linked to a geographical area, i.e., the city. However, individual efforts have small chance of success in the pursuit of global collective goals such as sustainability (Hansson, 2010). Sharing knowledge and the cooperation between cities are thus important components of any global strategy to achieve such goals.

Of course, it is undeniable that the tool continues to have a marked commercial intention, i.e. to sell Swedish technological solutions to urban and environmental problems. Hult (2013:90) argues that "Swedish political institutions [...] identified a remarkable chance to combine good will with 
possible profitable trade." I would add that the message has evolved and improved its ability to bend, i.e. to shift between cooperation and commercial interests, as well as between a people-centered and a technology-centered approach. Maybe Hult's epilogue forecasted the imminent influence that previous experiences had taught Swedish delegations regarding the difficulty of translating imaginaries with a top-down approach. Besides this enormous challenge, such a tool still faces the need of conveying a message of flexibility and adaptability, instead of rigidity and space-and-context conditionality; a message that includes the existing socio-technical systems and values with which any implemented solution will have to interact in every single one of the potential markets it is aimed at. Mixing important and relevant actors, and paying attention to their roles and ability to influence transitions into sustainability, might be an appropriate strategy to follow.

\section{Acknowledgements}

The author would like to thank ÅForsk and the Swedish Governmental Agency for Innovation Systems (Vinnova) for their financial support, and Em. Professor Leo Baas, Johannes Matschewsky, and Wisdom Kanda for their valuable contributions. Also, a big thank you to the anonymous reviewers, Marie Andersson de Frutos and Thomas Andersson from the Swedish Embassy in Colombia, and Christer Öjdemark from Envac AB.

\section{Notes}

1. The definition used here was suggested by Gareth Lofthouse, Economist Intelligence Unit (2004). In transitional societies, population growth has stagnated or is decreasing. They have also gained certain financial and political abilities to respond to environmental, social and economic challenges. Two additional classifications are "mature" and "emerging" societies.

\section{Note on contributors}

Santiago Mejía-Dugand is a researcher from the Division of Environmental Technology and Management at the Linköping University, Sweden. His research interests focus on the role that the different actors influenced by technological interventions play before, during and after implementation, and on the dynamics of socio-technical regimes at the urban level. 


\section{References}

J.A. Botero García and G.A. López Álvarez, "Economía, Política Económica y Servicios Públicos. Medio Siglo de las Empresas Públicas de Medellín" [Economy, Economic Policy and Public Services. Half a Century with Empresas Públicas de Medellín], Letras Jurídicas 10:1 (2005) 77-104.

M. Bulu, "Upgrading a City Via Technology," Technological Forecasting \& Social Change 89 (2014) 63-87.

A. DiGaetano and E. Strom, "Comparative Urban Governance. An Integrated Approach," Urban Affairs Review 38:3 (2003) 356-395.

A. Eriksson and G. Nilsson, “Tjänsteexport av Kommunal Miljöteknik - En Exportmarknad på Uppgång?” [Export of Consultancy Services of Environmental Technology from Municipalities - An Export Market on the Rise?], Master's Thesis (Linköping University: Environmental Technology and Management, Department of Management and Engineering, 2013).

Gareth Lofthouse, Economist Intelligence Unit (Eds.), Megacity Challenges - A Stakeholder Perspective (Munich: Siemens AG, 2004).

S.O. Hansson, "Technology and the Notion of Sustainability," Technology in Society 32 (2010) 274279.

M. Huesemann and J. Huesemann, Techno-fix - Why technology won't save us or the environment (Gabriola Island, Canada: New Society Publishers, 2011).

A. Hult, "Swedish Production of Sustainable Urban Imaginaries in China," Journal of Urban Technology 20:1 (2013) 77-94.

Institutet för Tillväxtpolitiska Studier (ITPS), Svensk miljöteknik [Swedish environmental technology] (Östersund: ITPS, 2008) <http://www.tillvaxtanalys.se/download/18.56ef093c139bf3ef89027d9/1349863459353/svenskmiljoteknik-08.pdf> Accessed September 10, 2014.

K. Kairento and M. Nygårds, "Export of Municipal Environmental Technology Knowledge. An Analysis of Previous Activities and Incentives," Master's Thesis. (Linköping University: Environmental Technology and Management, Department of Management and Engineering, 2014).

W. Kanda, S. Mejía-Dugand and O. Hjelm, "Governmental export promotion initiatives: awareness, participation, and perceived effectiveness among Swedish environmental technology firms," Journal of Cleaner Production 98 (2015) 222-228.

H.B. Kappes and G. Oettingen, "Positive fantasies about idealized futures sap energy," Journal of Experimental Social Psychology 47 (2011) 719-729.

C. McFarlane, "The comparative city: knowledge, learning, urbanism," International Journal of Urban and Regional Research 34:4 (2010) 725-742.

S. Mejía-Dugand, "Diffusion of environmental technology in a megacity - A case study of Mexico City," Licentiate thesis No. 1574 (Linköping: Linköping Studies in Science and Technology, 2013).

S. Mejía-Dugand, O. Hjelm and L.W. Baas, "Diffusion of environmental technology: an analysis of export strategies in Sweden," in S. Mejía-Dugand, Diffusion of environmental technology in a megacity - A case study of Mexico City (Linköping: Linköping Studies in Science and Technology, 2013a) Appended article No. 3.

S. Mejía-Dugand, O. Hjelm, L. Baas and R.A. Ríos, "Lessons from the spread of Bus Rapid Transit in Latin America," Journal of Cleaner Production 50 (2013b) 82-90.

G. Oettingen and D. Mayer, "The motivating function of thinking about the future: Expectations versus fantasies," Journal of Personality and Social Psychology 83:5 (2002) 1198-1212.

S. Pandis Iveroth, "Industrial ecology for sustainable urban development - The case of Hammarby Sjöstad," PhD Thesis (Stockholm: Universitetsservice US-AB, 2014).

S. Pandis Iveroth, S. Johansson and N. Brandt, "The potential of the infrastructural system of Hammarby Sjöstad in Stockholm, Sweden," Energy Policy 59 (2013a) 716-726.

S. Pandis Iveroth, A. Vernay, K.F. Mulder and N. Brandt, "Implications of systems integration at the urban level: the case of Hammarby Sjöstad, Stockholm," Journal of Cleaner Production 48 (2013b) 220-231.

E.M. Rogers, "Diffusion of preventive innovations," Addictive Behaviors 27 (2002) 989-993.

R.W. Stevens, ed., Appropriate technology - A focus for the nineties (New York: Intermediate Technology Development Group of North America, 1991). 
B. Stöttinger and B.B. Schlegelmilch, "Explaining export development through psychic distance: enlightening or elusive?" International Marketing Review 15:5 (1998) 357-372.

Sveriges Miljöteknikråd (SWENTEC), Slutbetänkande av Sveriges miljöteknikråd [Final report of the Swedish Environmental Technology Council] (Stockholm, Sweden: Swentec, 2010) <

http://mb.cision.com/Public/MigratedWpy/95895/9061959/ad59f0df1a83a69e.pdf> Accessed September 10, 2014.

The Swedish Government, Referensgruppsuttalande: Svensk miljöteknik i världen. Hur kan vi bli en stark global spelare? [Declaration of the reference group: Swedish environmental technology in the world. How can we become a strong global player?] (Stockholm, Sweden: The Swedish Government, 2008)

$<$ http://www.regeringen.se/content/1/c6/10/81//90/5f3b7cf5.pdf> Accessed October 10, 2012.

The Swedish Government, Strategi for utveckling och export av miljöteknik. 2011-2014 [Strategy for development and export of environmental technology 2011-2014] (Stockholm, Sweden: The Swedish Government, 2011) <www.regeringen.se/sb/d/14218/a/174071> Accessed May 27, 2012.

J. Wangel, "Hur hållbara är Hammarby Sjöstad och Nörra Djurgårdsstaden? [How sustainable are Hammarby Sjöstad and Nörra Djurgårdsstaden?]," in H. Teleman, ed., Hållbarbetens villkor (Malmö: Bokförlaget Arena, 2013) pp. 86-103.

WWF, Coming clean: The global cleantech innovation index 2014 (Västerås, Sweden: Edita Västra Aros AB, 2014) $<$ http://awsassets.panda.org/downloads/wwf_report__global_cleantech_innovation_index_2014_final _.pdf $>$ Accessed August 25, 2014.

Yale University, Environmental Performance Index (New Haven, CT: Yale University, 2014) < http://epi.yale.edu> Accessed August 25, 2014. 